\title{
Potential Analysis On Solar District Heating in China
}

\author{
Huang, Junpeng; Fan, Jianhua; Furbo, Simon
}

Publication date:

2015

Document Version

Publisher's PDF, also known as Version of record

Link back to DTU Orbit

Citation (APA):

Huang, J., Fan, J., \& Furbo, S. (2015). Potential Analysis On Solar District Heating in China. Paper presented at ISES Solar World Congress 2017, Abu Dhabi, United Arab Emirates.

\section{General rights}

Copyright and moral rights for the publications made accessible in the public portal are retained by the authors and/or other copyright owners and it is a condition of accessing publications that users recognise and abide by the legal requirements associated with these rights.

- Users may download and print one copy of any publication from the public portal for the purpose of private study or research.

- You may not further distribute the material or use it for any profit-making activity or commercial gain

- You may freely distribute the URL identifying the publication in the public portal

If you believe that this document breaches copyright please contact us providing details, and we will remove access to the work immediately and investigate your claim 


\title{
Potential Analysis On Solar District Heating in China
}

\author{
Junpeng Huang1, Jianhua Fan² and Simon Furbo ${ }^{2}$ \\ 1 Department of Civil Engineering, Technical University of Denmark, Copenhagen \\ (Denmark) \\ 2 Department of Civil Engineering, Technical University of Denmark, Copenhagen \\ (Denmark)
}

\begin{abstract}
Abstract: This paper analyzes the potential of solar district heating (SDH) in China from the perspective of incentive policy making, selection of technology solutions, regional adaptability and economic feasibility for clean heating. Based on the analyzation, this paper proposes a road map for the development of SDH, and predicts its market potential in China.
\end{abstract}

Key words: solar district heating, potential analysis, road map, $13^{\text {th }}$-Five-Year Plan

\section{The urgency moving from coal to clean energy}

China's urbanization rate is currently only $54.8 \%$, leaving a huge potential for future growth. Over the past decade, increasing heating requirements have led to the fast deployment of district heating systems in big cities, as shown in Fig.1, the heating area increased from 2.5 billion $\mathrm{m}^{2}$ to 6.7 billion $\mathrm{m}^{2}$ in the past 10 years from 2005-2015. Meanwhile although rural population has been decreasing, rural energy demand most notably for heating has also been increasing steadily. This rise has been on par with economic development and improvements in lifestyle. District heating is therefore increasingly being deployed to meet heating loads in rural regions.

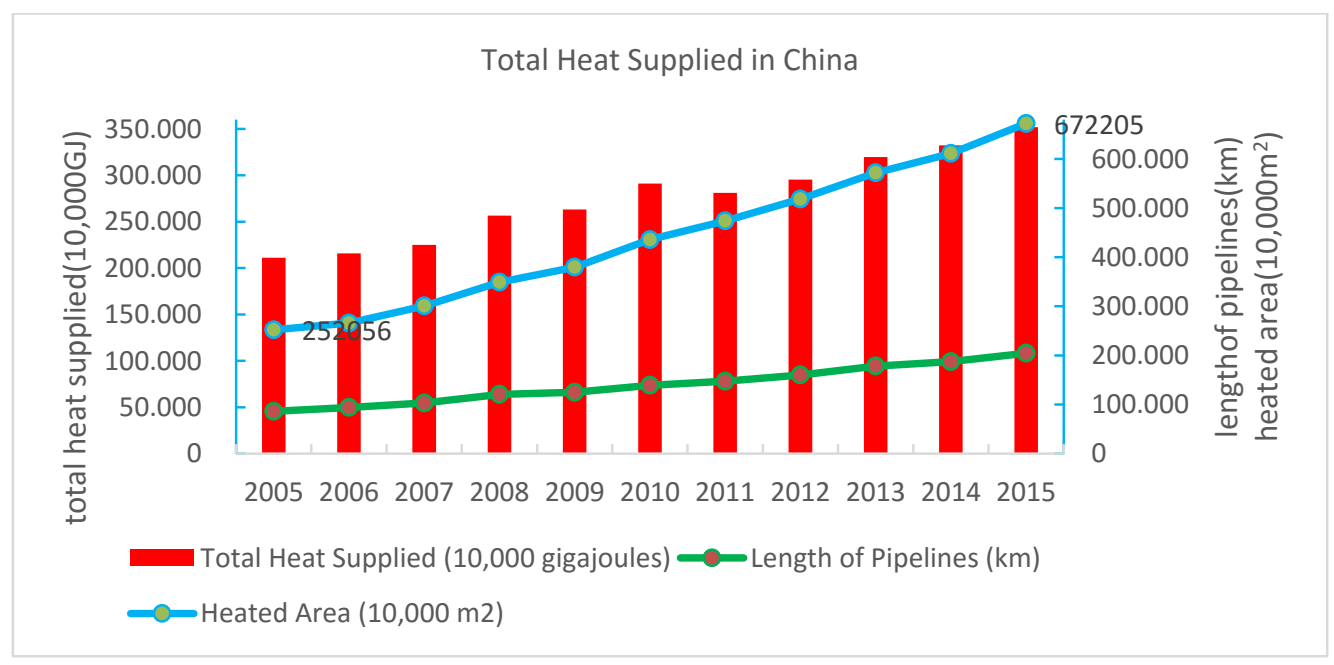

Fig. 1: Growth of the heating capacity in China ${ }^{1}$

To cope with the rapidly increasing demand for heating, authorities have deployed district heating systems throughout north of the country. However, as shown in Fig.2, district heating systems in China are coal intensive, accounting for $81 \%{ }^{2}$ of the total heating energy, which caused serious air pollution. It's reported that over 366,000 people died earlier from diseases in China in 2013 caused by air pollution due to burning of coal ${ }^{3}$. 


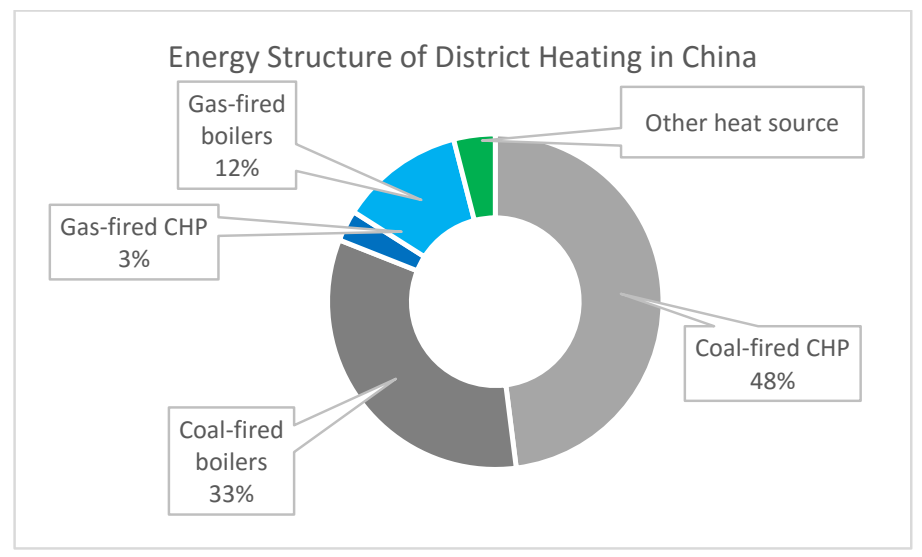

Fig. 2: Energy structure of district heating in China

According to the Sino-US Joint Statement on Climate Change ${ }^{4}$, China will reach its $\mathrm{CO}_{2}$ emission peak in 2030 , and will increase the share of non-fossil energy to $15 \%$ by $2020,20 \%$ by 2030 . But there is a big gap from the objectives until now. Only taking Beijing as an example, by the end of 2015, the proportion of renewable energy in total heating energy consumption is only $0.8 \%$. To increase the proportion of non-fossil fuels accounted for primary energy consumption, large-scale using solar heating is imperative.

\section{Why solar district heating}

$50 \%$ of total air pollution source comes from coal consumption in China, especially in rural area, raw coal ( $\sim 80 \%$ bituminous and $\sim 20 \%$ anthracite) is often consumed in stoves with low efficiency. In 2013 , Chinese government published Air Pollution Control Action Plan, which set a target for coal reduction, by 2017, consumption of coal will fall to below $65 \%$ in terms of total energy consumption. Beijing-Tianjin-Hebei Province, the Yangtze River Delta and the Pearl River Delta will try to achieve negative growth of total coal consumption.

To fulfill this target quickly and effectively, the government takes two main strategies which are called Coal to Gas and Coal to Electricity, with a subsidy policy on clean heating transformation. Now, these two strategies are widely used under the emission reduction pressure and being stimulated by subsidy policy. From the actual implementation effect of view, these two strategies may reduce the raw coal combustion temporarily, but there're still problems on the real effect of reducing air pollution and the sustainability of policy.

\subsection{Coal to Gas is difficult to be applied widely}

Coal to Gas in power plants was first implemented in Beijing and quickly adopted by other cities. However, currently most of them have suspended or canceled the initiative, mainly because natural gas is still scarce and costly in China.

High natural gas prices, increased burden of heating companies, it is difficult for long-term stable operation. In addition to the initial expenditure for transformation of equipment, the using cost is also great. The price of natural gas per kWh is about 3-5 times the price of coal with the same thermal value. Due to fuel costs rose sharply, and government subsidies declined year by year, many small heat companies which have completed the coal to gas transformation tend to change back to coal-fired boilers.

Evidence show that Coal to Gas also indirectly results in wind power curtailment and PV power curtailment. At present, the wind power and PV installed mainly concentrated in the "Three North" area (northeast, northwest, North China), accounting for $77 \%$ and $68 \%$ of the country with large-scale centralized development. During heating season due to the output power of CHP is determined by heat demand, which makes the CHP units less flexible, power supply surplus, which leads to huge wind and PV power 
curtailment. According to "China Building Energy Annual Development Research Report 2017"5, in "three North" area, the amount of abandoned wind power in 2015 was 9.48 TWh, 8.34 TWh and 16.55TWh, accounting for $99.9 \%$ of the total abandoned wind power. From the time distribution point of view, $67 \%$ of the country, more than $90 \%$ of the northeastern region, wind power curtailment occurred in the heating season.

In 2016, the natural gas gap between supply and demand reached 60 billion $\mathrm{m}^{3}$ in China, and it's estimated that the gap will reach 130 billion $\mathrm{m}^{3}$ by 2020 , which means there would be not enough gas supply for a lot of households installed gas boilers when the heating demand reaches to peak. Natural gas is currently easy to be accessed in urban areas, but the infrastructure for gas supply in rural area is still under plan or under construction. Coupled with the difficulty of laying the gas pipe network, high costs, not sufficient gas production and other factors, the Coal to Gas strategy is difficult to be applied widely.

\subsection{Coal to Electricity is difficult to be sustained}

Coal to Electricity means replacing coal-fired boilers with low-temperature air-source and ground-source heat pumps, in some cities, including regenerative electric boilers, but direct heating types of electric heater are prohibited by this program. The government will provide about $\$ 3,600$ subsidies per household for heating equipment, and additional 0.6 US cent per kWh electricity price subsidies in heating season, almost reducing $2 / 3$ cost for using electric heating equipment.

But the Coal to Electricity is also in dispute on cleanness and the sustainability of subsidy policy.

Most of the electricity used in Beijing, Tianjin and Hebei comes from the off-peak electricity in Inner Mongolia, and the main source is coal. The implementation of Coal to Electricity is a method with rob Peter to pay Paul, and finally pollution will eventually be grafted to the western region.

Another disputation is the heavy financial burden. Taking Beijing as an example, it is expected that there will be 1.1 million households finishing the Coal to Electricity transformation at the end of $13^{\text {th }}-5$-Years Plan. If calculating in accordance with maximum subsidy of 10 thousand $\mathrm{kWh}$ per household, the government needs 334 million US dollars in the following years. In addition, to reduce the burden on the residents, the government must invest substantial money to improve thermal insulation performance for the residents' houses.

So, the Coal to Electricity is not a problem for cities with higher economic level, but it is unsustainable in economically backward areas. Therefore, coal reduction cannot engage in "one size fits all", and solar-aided energy systems that integrating multi-energy types and multi-heat sources, such as geothermal energy, biological energy and other clean energy should also be valued to replace the scattered coal combustion.

\subsection{Advantages of solar district heating}

Compared with Coal to Gas and Coal to Electricity technologies and policies, SDH is the only strategy to substitute fossil energy completely, which will also improve energy security by reducing energy imports, especially natural gas importation for China.

The most advantage of SDH for end users is the great operating cost savings. In a combination system of solar and gas boiler, solar will contribute $66.6 \%$ energy cost savings by saving gas consumption ${ }^{22}$ in Hebei area, for a solar combined with air-source heat pump heating system, solar will contribute $45.6 \%$ energy cost savings in Xi' an $\mathrm{City}^{23}$.

SDH can also create local jobs related to the manufacturing, commercialization, installation and maintenance of solar thermal systems.

\section{Feasibility of SDH in China}

\subsection{Stringent environmental protection pressure national wide}

To deal with the serious air pollution problem, the Chinese government has made systematic favorable 
policies for clean energy space heating.

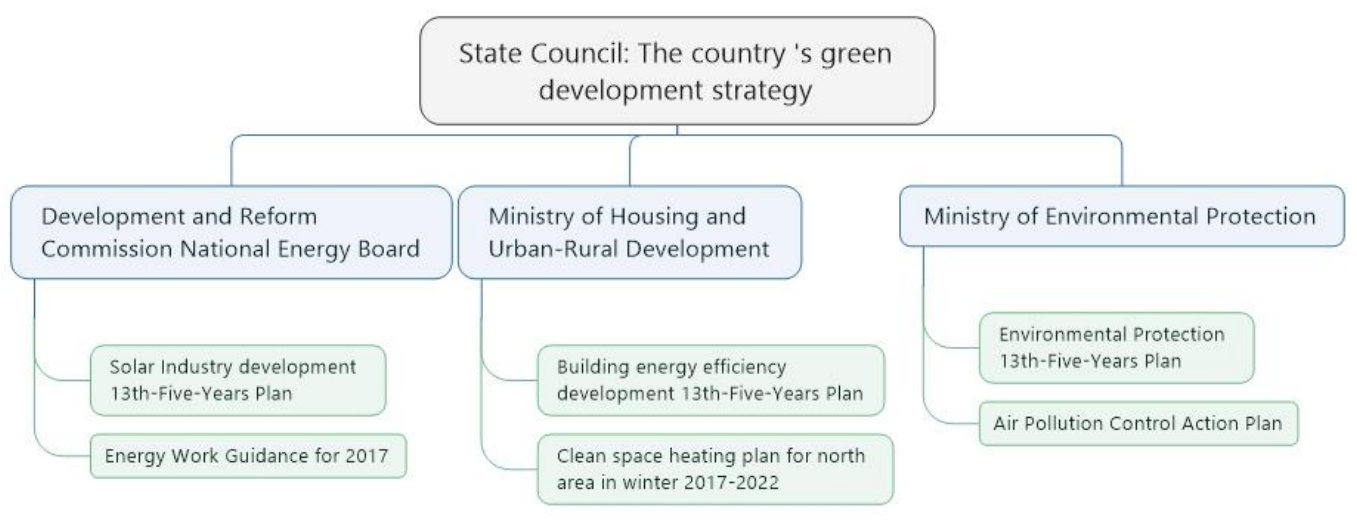

Fig. 3: Favorable policy structure for clean heating in China ${ }^{6}$

The detailed indexes and targets which address clean heating issued by different government departments:

Table.1 Regulations and Plans on Clean Heating and Renewable Development in China

\begin{tabular}{|c|c|}
\hline Regulations and Plans & Indexes and Targets \\
\hline $\begin{array}{l}\text { Solar Energy } \\
\text { Development } 13^{\text {th }}-5 \text {-Years } \\
\text { Plan }\end{array}$ & $\begin{array}{l}\text { In } 2020 \text { and 2030, non-fossil energy accounted for } 15 \% \text { and } 20 \% \text { of the } \\
\text { primary energy consumption. In } 2020 \text {, the number of large SDH stations in } \\
\text { suitable areas reached more than } 200 \text {, the total area of collector is more than } \\
4 \text { million square meters. Combined with the construction of New } \\
\text { Countryside, more than } 3 \text { million demonstration projects of solar hot water } \\
\text { and solar heating in rural areas will be promoted nationwide. }\end{array}$ \\
\hline $\begin{array}{l}\text { Renewable Energy } \\
\text { Development } 13^{\text {th }}-5 \text {-Years } \\
\text { Plan }\end{array}$ & $\begin{array}{l}\text { In } 2020 \text { and } 2030 \text {, the proportion of non-fossil energy in primary energy } \\
\text { consumption reached } 15 \% \text { and } 20 \% \text { respectively. } \\
\text { In } 2020 \text {, all types of renewable energy substitute about } 1.5 \text { tce in heating and } \\
\text { civilian fuels, in which, solar thermal utilization (heating and hot water) } \\
\text { reached } 800 \text { million square meters, equivalent to } 96 \text { million tce. }\end{array}$ \\
\hline $\begin{array}{l}\text { Energy Development } 13^{\text {th }} \text { - } \\
\text { 5-Years Plan }\end{array}$ & $\begin{array}{l}\text { In } 2020 \text {, the supply capacity of non-fossil energy reached } 750 \text { million tce, } \\
\text { the proportion of non-fossil energy consumption increased to more than } \\
15 \% \text {. }\end{array}$ \\
\hline $\begin{array}{l}\text { Building Energy } \\
\text { Efficiency and Green } \\
\text { Building Development } \\
13^{\text {th }}-5 \text {-Years Plan }\end{array}$ & $\begin{array}{l}\text { In } 2020 \text {, renewable energy substitutes conventional energy consumption } \\
\text { accounted for more than } 6 \% \text { in civil buildings. } \\
\text { The new solar thermal application area will reach to more than } 2 \text { billion } \\
\text { square meters in buildings. }\end{array}$ \\
\hline $\begin{array}{l}\text { Suggestions on Promoting } \\
\text { Renewable Energy } \\
\text { Heating }\end{array}$ & $\begin{array}{l}\text { In } 2020 \text {, renewable energy heating area reached } 3.5 \text { billion square meters, } \\
\text { Beijing, Tianjin and surrounding areas up to } 1 \text { billion square meters, Solar } \\
\text { heating reached } 400 \text { million square meters nationwide. }\end{array}$ \\
\hline $\begin{array}{l}\text { Air Pollution Prevention } \\
\text { and Control Action Plan } \\
(2013-2017)\end{array}$ & In 2017 , the proportion of non-fossil energy consumption increased to $13 \%$. \\
\hline
\end{tabular}




\subsection{Choose suitable region}

China has abundant solar resources, equivalent to 1.7 trillion tons of standard coal equivalent (tce) per year ${ }^{7}$, but most Chinese cities are densely populated with high land price and limited places for installation of solar collectors. So, at the beginning phase for solar district heating(SDH) in China, the most suitable area for developing large-scale solar heating is the area with rich solar resources, longer heating period, many free lands available, and no power grids and gas pipe network coverage, such as Tibet, Gansu, Tsinghai provinces.

In the outskirts of the central city, as well as rural areas without municipal heating infrastructure, it is also appropriate to develop small SDH pants to reduce the use of coal, while creating the conditions for using of rural biomass and municipal solid waste incineration.

\subsubsection{North urban area}

Heating in urban areas of northern China is mostly district heating, including many city level heat supply network and community level heat supply network. According to the heat source and size, heating systems can be divided into cogeneration, regional coal fired boiler, gas boiler, residential area coal-fired boiler, gas boiler, heat pump residential district heating etc.; And household gas stove, household coal stove, air conditioning heating, direct electric heating etc.

The heating area of Chinese cities reached 12.6 billion $\mathrm{m}^{2}$, and the energy consumption of heating in northern cities was 184 million tce, accounting for $21 \%$ of total building energy consumption in 2014. In 2001 2014, the heating area of northern urban buildings increased from 5 billion $\mathrm{m}^{2}$ to 12.6 billion $\mathrm{m}^{2}$, increased by 1.5 times, the total energy consumption increased less than 1 times, the total energy consumption growth was significantly lower than the growth of construction area. The heating energy consumption per square meter decreased from $22.8 \mathrm{~kg}$ tce $/ \mathrm{m}^{2}$ in 2001 to $14.6 \mathrm{~kg} / \mathrm{m}^{2}$ in 2014 , and the energy consumption per square meter decreased by $34 \%{ }^{25-26}$.

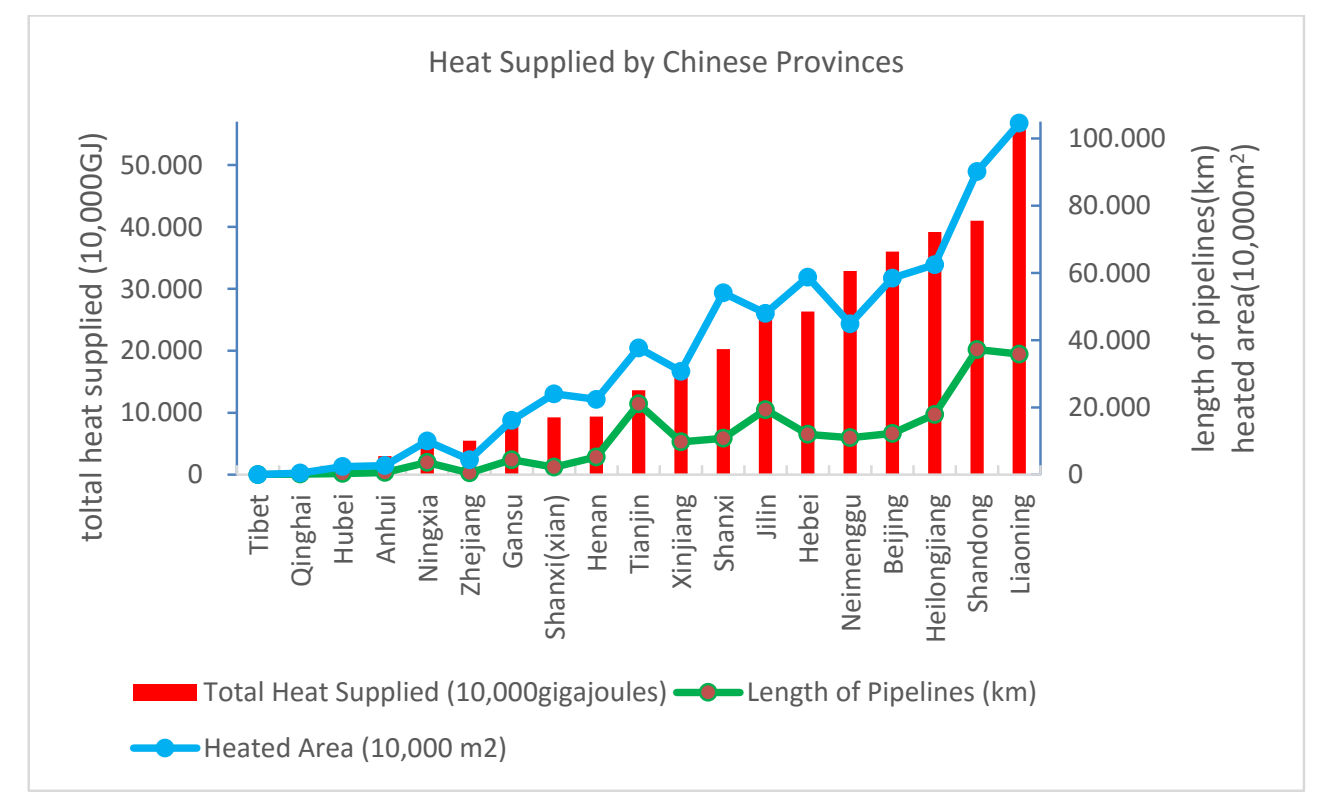

Fig. 4: Heat supplied by Chinese Provinces ${ }^{1}$

The vast existing heating area means great potential for clean heating transformation, and a good opportunity for solar heating, but there're great challenges from the economic point of view.

Affected by the welfare heating system under the planned economy, most residential heating systems are single pipe vertical series system, in which vertical imbalance is serious, uneven heat and cold between high 
and low stories of buildings, difficult to achieve heat charging by metering. At the same time, heating equipment obsolete, poor reliability, lack of advanced heat metering means ${ }^{12}$.

"Heat" as a commodity is not accepted by users and part of enterprise, it is difficult for users to change from the welfare heating system to buy heat, auxiliary heat metering equipment is expensive, the reform from the tandem network to metering per household is difficult.

The urban area has large population density, high land price, and limited installation space for solar collectors. In the short term, it is not the best choice for developing SDH. But the heating demand of urban area is large and the users are concentrated. The economic and environmental benefits from SDH are more significant, which will be the focus of future development.

\subsubsection{North Rural areas}

The northern rural heating mainly relies on heated brick bed, hot wall, household coal stove, gas stove, electric heating and solar assisted biomass boiler heating in some developed rural area around Beijing and Tianjin, some rural areas also develop small district heating systems.

Zhang Wei of Tianjin University summarizes the current heating technologies, heating fuel in north rural area, household evaluation of indoor thermal comfort, and the distribution of heating technologies based on a survey to rural residential buildings in the cold area between 2007 and 2010²7. As shown in Fig.5, small coal fired boilers and heated brick beds are the main heating solution for rural area, accounting for $84 \%$ in total.

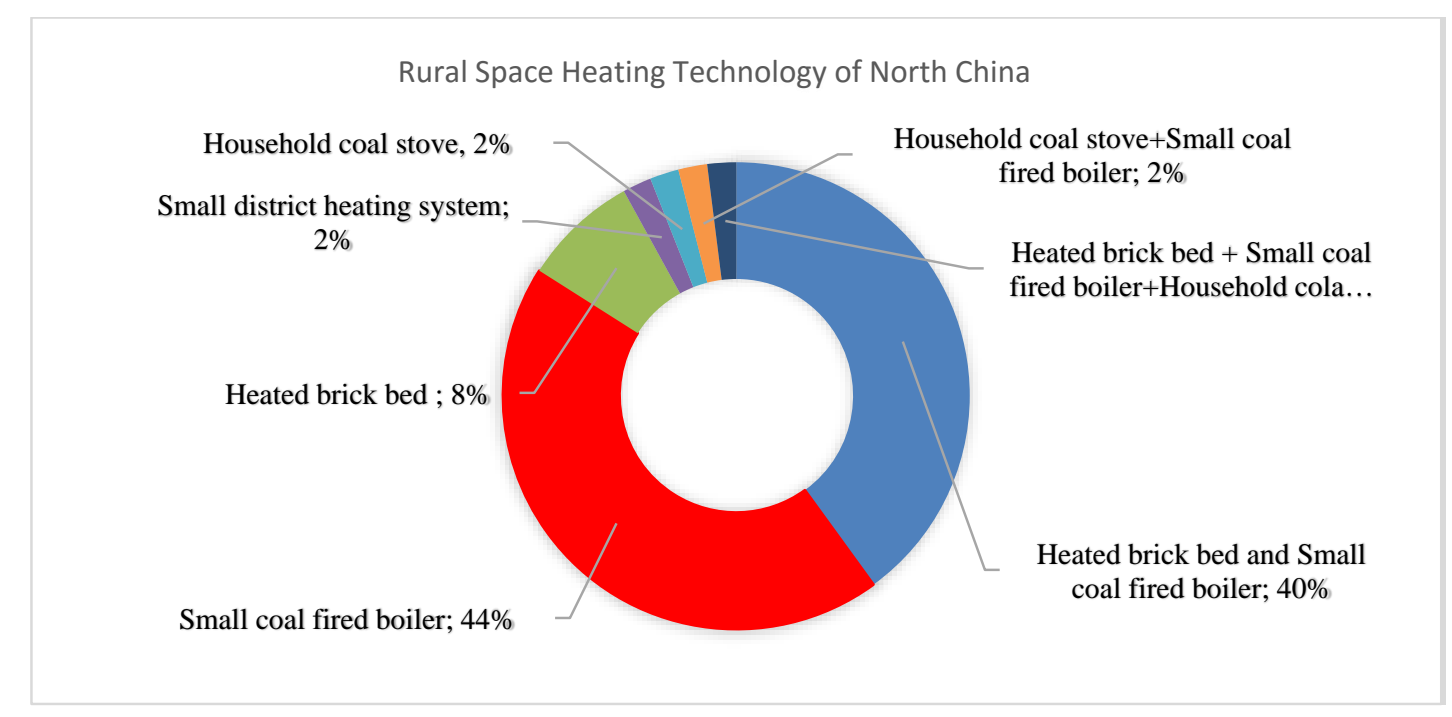

Fig. 5: Rural Space Heating Technologies in North China

There are many deficiencies for current heating solutions in rural heating in North China, such as low indoor temperature, large heating energy consumption, serious pollution and so on. Energy utilization rate of heated brick bed and hot wall is about $60 \%$, stove is only $40 \%$, while no insulation measures for heating pipes, the heat loss of pipelines is large. Heating safety is not guaranteed, the improper operation or design easily lead to gas leakage, and even explosion accident, stove heating easily leads to carbon monoxide poisoning ${ }^{28}$.

In terms of district heating in rural area, Shandong province is far more developed than other provinces. Beijing, Shanxi, Liaoning, Heilongjiang and Hebei have developed rapidly.

Rural and small towns in northern China are good places for developing large-scale SDH projects due to cheap lands, backward heating pipe network infrastructures, serious air pollutions caused by raw coal burning, and the great pressure to improve quality of life. 


\subsubsection{South Area}

Air conditioning is still the largest portion of household heating in South China, reaching $30 \%{ }^{1}$. Due to the short heating time in South China, even if the heating effect is not good, many families still use air conditioning as the only heating source, to save a large amount of installation of other heating equipment. Household gas-fired boilers and electric floor heating accounted for $1 \%$ and $0.1 \%$ in southern households, respectively. The heat pump as a relatively new product, accounting for only $0.03 \%$. With characteristics of energy saving and environmental protection, more suitable for the southern climate, heat pumps are currently the fastest growing household heating products in the South. Affected by the rainy, not enough sunshine time and other factors in the south, solar heating applications are relatively limited, accounting for only $0.005 \%$.

Short heating time in southern China, usually about 1-3 months, household heating dominates, not conducive to develop SDH. In order to reduce operating costs, residential property management companies are also considering adding a solar collector field on the existing heating system.

\subsection{Choose suitable technologies}

Although China shares $71 \%$ of the total installation of solar collectors in the world, but no more than $0.3 \%$ of solar collectors have been used for solar heating ${ }^{8}$, as shown in Fig.6, there're only $154,971 \mathrm{~m}^{2}$ solar collectors used for heating, accounting for $0.3 \%$ of the annual production in 2014 in China. Most of solar collectors were used in rural area as a home appliance, solar water heaters.

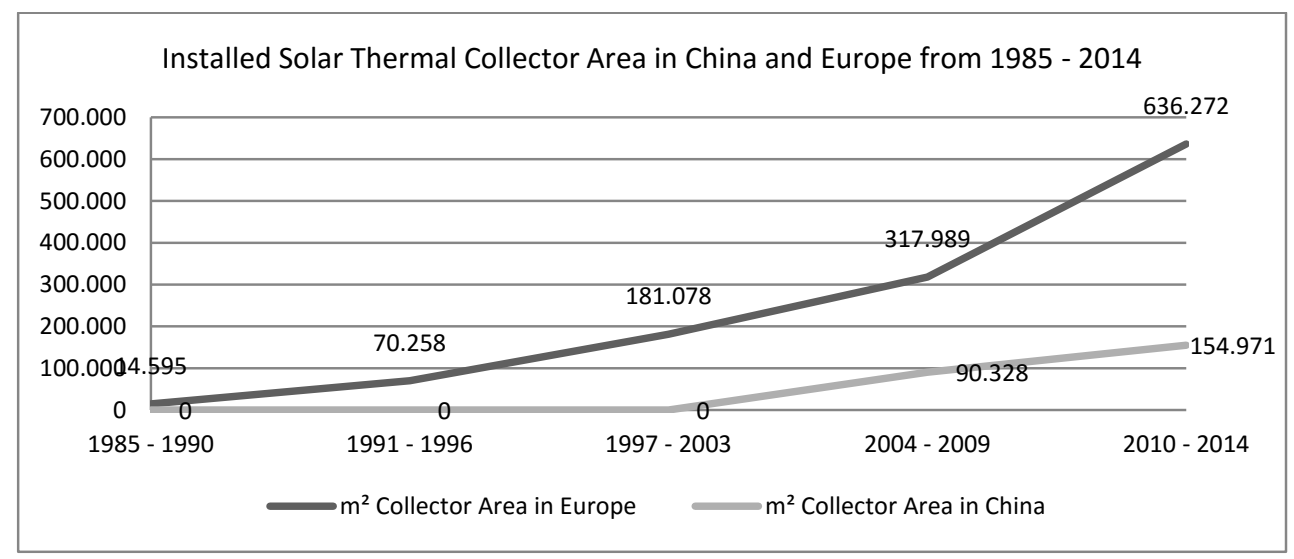

Fig. 6: China-EU collector installation area for solar heating'

\subsubsection{Centralized solar heating system is better than household solar heating}

Solar heating has been used for more than 10 years in China, and is widely used in rural areas as household heating in the early stage. In recent years, solar heating has gradually developed into schools, public buildings and residential communities etc. Without municipal heating.

Year 2016, we conducted a post-survey on some solar household heating projects in Beijing rural villages(Fig.7). The on-site survey reveals that solar heating system can save more than $50 \%$ of the coal burning annually, but it doesn't run steadily. Caused by the easily damaged all-glass vacuum tube solar collectors and bad installation, there're lots of deficiencies found after 2 years' installation, e.g. leaking in the pipelines and water tanks. The operation and maintenance of household heating system mainly conducted by the user personal, due to lack of professional knowledge, many users face the helplessness when the system fails. But it is easier to build a regional operation and maintenance service points in a centralized heating station than decentralized household heating. 


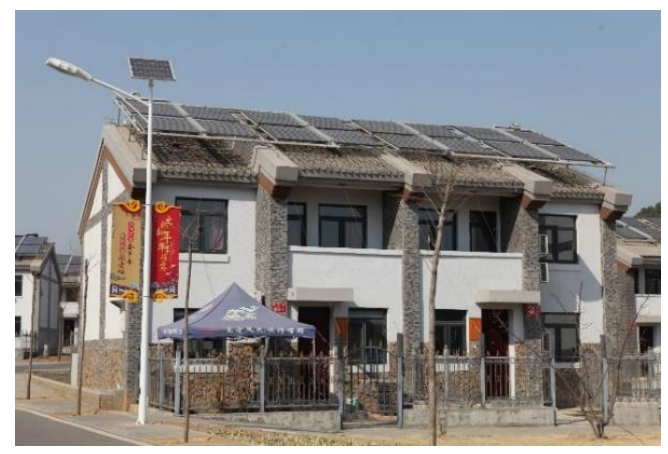

A farmhouse heated by solar energy

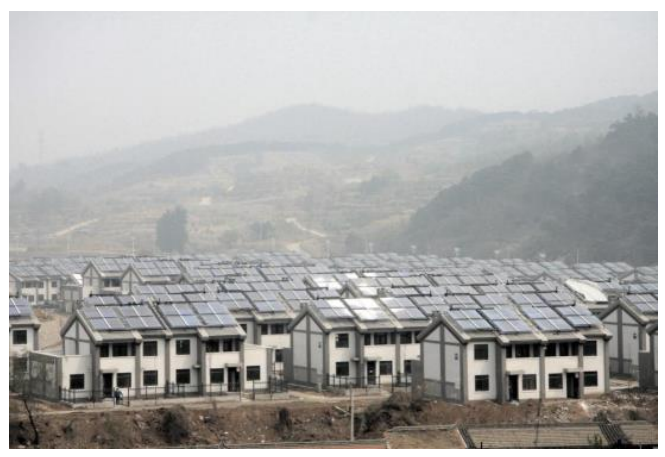

A village with solar heating

Fig. 7: Typical household solar heating project in rural areas of Beijing

After more than 10 years of rural solar heating pilot and experience accumulation, from the economy, safety and operation and maintenance work convenience point of view, the author thinks that district heating with solar and biomass as the main heat source is more suitable than household heating in rural areas.

\subsubsection{Flat plate solar collector is better than all-glass vacuum tube solar collector}

The authors investigated many solar heating projects in northern China. All-glass vacuum tube solar collectors are mostly used in those household solar heating systems. Due to poor maintenance and improper operation, the real life span for all-glass vacuum tube solar collectors is only 2-3 years. Many all-glass vacuum tube solar collectors are broken for overheat or freezing in the first year since installation. The Investigation Report on Solar Heating Demonstration Projects in Mentougou of Beijing (ICA, 2010) gives the same suggestions, for solar heating projects, flat plate solar collector with simple structure, long service life and low maintenance rate should be preferentially selected.

\subsubsection{Solar heating can prolong the life of existing ground source heat pump system}

In the past more than 10 years, part of local Chinese government in cold northern area promoted ground source heat pump (GSHP) heating, only in Shenyang City, GSHP heating area reached 59.41 million square meters in 2012, accounting for nearly $1 / 3$ of the city's total heating area. But now, there are many residential communities with GSHP heating system cannot get normal heating because of long term imbalance between heating and cooling.

Because heating load in winter is greater than cooling load in summer in cold areas, the heat extracted from the underground soil by GSHP systems is much greater than the heat injected to the soil, which makes the soil temperature decreasing yearly. The lower soil temperature will decrease the system's evaporation temperature in winter, reduce the heating capacity, and increase the energy consumption. According the Study on Heat Balance of Ground Source Heat Pump in Severe Cold Area ${ }^{11}$, when soil temperature decreases by $1{ }^{\circ} \mathrm{C}$, the energy consumption of the GSHP will increase by $3-4 \%$.

Solar collectors can be added to those dysfunctional GSHP systems to form a hybrid energy heating system. With proper control strategies, this hybrid energy system can achieve direct solar heating, direct heat pump heating, heat injection from solar collectors in summer and heat extraction by GSHP in winter, and prolong the life span of GSHP systems, at the same time improve the system energy efficiency.

\subsection{Economic feasibility}

There are mainly two district heating models in China - district boiler heating and district CHP heating, the fuel is coal or gas. This paper selects a Chinese standard building (heating index: $50 \mathrm{~W} / \mathrm{m}^{2}$ ) in Xi' an as a sample, with $10^{6} \mathrm{~m}^{2}$ heating area, 50MW heating load. Suppose the efficiency of coal fired boiler is 0.68 , 
gas fired boiler is 0.9 ; pipe network transmission efficiency is 0.9 . The heating mode is setting as single heat source, double pipe heating system. Based on a 25 years' payback time, we can calculate the heat price and analysis the economy for different district heating technologies ${ }^{13}$.

Based on land cost, energy price, O\&M cost etc. in China, we analyze the economy of SDH in China with successful models from Denmark. The annual global solar irradiance is $1247.4 \mathrm{KWh} / \mathrm{m}^{2}$.a in Xian, total district heating load is $144 \mathrm{GWh} / \mathrm{a}$, heating time is 2900 hours, designed solar fraction is $20 \%$, the price for different energy in Xi'an is shown in Table.2.

Table.2 Basic assumptions and price structure in Xi'an

\begin{tabular}{r|c}
\hline Biomass & $29.5 \$ / \mathrm{MWh}$ \\
\hline Electricity & $149.6 \$ / \mathrm{MWh}$ \\
\hline Power grid price & $225.0 \$ / \mathrm{MWh}$ \\
\hline Bank loan interest rate & $5 \%$ \\
\hline Years of investment & $25 \mathrm{Year}$ \\
\hline
\end{tabular}

According to the above design parameters and prices of fuels, we analyzed the economy for four SDH systems in China by means of the SUNSTORE4-Feasibility-Evaluation-Tool ${ }^{12}$. And the heating prices is shown in Fig. 8 based on 25 years' payback time. Solar collector area is $144,300 \mathrm{~m}^{2}$ for all district heating systems, the volume of PTES is $288,600 \mathrm{~m}^{3}$, BTES is $1,154,400 \mathrm{~m}^{3}$, and TTES is $31,746 \mathrm{~m}^{3}$.

Table.3 Four types of SDH technologies combination

\begin{tabular}{c|l}
\hline Types & Technologies combination \\
\hline SDH1 & Solar + Biomass + HP + Pit Thermal Storage \\
\hline SDH2 & Solar + Biomass + Pit Thermal Storage \\
\hline SDH3 & Solar + Biomass + HP + Borehole Storage \\
\hline SDH4 & Solar + Biomass + Tank Thermal Storage \\
\hline
\end{tabular}

Coal is the mainly energy source in China, but the heating price of coal fired CHP is very high, so government allocates large amount of subsidy to coal fired CHP to maintain price competitive advantage. we calculate the heating price for traditional district heating technologies, heating price is very high, but the price of SDH systems are relatively low. SDH not only will save a lot of fossil fuels, but also reduce the heating price.

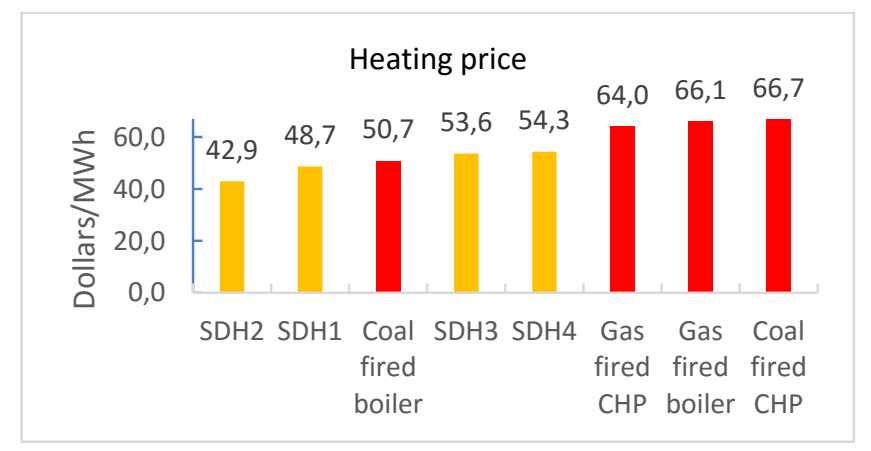

Fig. 8: Heating price of different district heating systems

From Fig.8, we can conclude that the heating prices of gas fired CHP, Gas fired boiler and coal fired CHP are very high; comparing heating price of the eight district heating systems, in the 50MW heating load condition, the heating price of SDH2 is the lowest, with a price $42.9 \$ / \mathrm{MWh}$, then SDH1, with a price $48.7 \$ / \mathrm{MWh}$; and the price of coal fired CHP is the highest, the heating price is $66.7 \$ / \mathrm{MWh}$. Generally, the heating price of SDH systems is lower than traditional CHP and gas fired boiler district heating. So SDH has 
price competitive advantage in China.

\section{Major barriers}

Although SDH has many benefits, it is still very difficult to implement this environmentally friendly clean heating technology in China. The major barriers include no demo project, and lack of mature supply chain support such as design, construction and operation of SDH plants. Besides the above-mentioned barriers, there're two facts for development of SDH in China.

\subsection{Backward idea}

When promoting SDH, the most common voice is that "land price is high" in China, this centralized solar heat station needs to take up a lot of land, completely inconsistent with China's national conditions. The reality is that, from an economic point of view, compared with conventional agriculture, the economic benefits of solar heat stations are much higher than those of agriculture, and due to the arrangement of collectors, a large interval distance is required, which makes the land can still develop livestock and facilities agriculture. In addition, in the sparsely populated, resource-poor Tibet, Gansu and other regions, as well as some areas with strict ecological protection requirements, $\mathrm{SDH}$ is the best choice.

\subsection{Difficult to be connected into existing heating pipe networks}

District heating technology in China is still the second generation, supply and return water temperature is higher in main pipe network, it's difficult for solar heating to be connected into existing heating pipe networks without a heat pump or reheat device ${ }^{17 \sim 18}$. In addition, space heating is mandatory in heating season as a livelihood project in China, but there's no heating demand in the rest of the year, which means a waste of solar energy in summer, or will increase the payback time of a SDH system. Therefore, to make full use of solar energy, improve annual solar fraction, building a seasonal heat storage facility is necessary ${ }^{19^{2}}{ }^{\circ}$.

\section{Huge market potential}

China's district heating capacity shows an increasing trend year by year, which is in line with the level of China's economic development, the demand for improving indoor thermal comfort in winter is becoming higher. Not only compulsory heating in North, the voice for heating in South in winter is also stronger in recent years. It can be predicted that district heating load will further increase in near future. Based on the analysis to the data of district heating capacity in recent ten years, we can get the annual growth rate of district heating capacity, about $9 \%$, we can predict the district heating capacity development trend in future 5 years by this growth rate. By 2020, China's district heating capacity will reach 727,100 MW, an increase of 254,544 MW compared with 2015, see Figure 10.

Assuming the annual solar irradiance is $800 \mathrm{~W} / \mathrm{m}^{2}$, the efficiency of high performance flat plate heat collector is 0.6 , transmission efficiency of pipe network is 0.9 , the average daily sunshine hours was $7 \mathrm{~h}$, the share of SDH used in clean energy heating is 5\%,10\%, 15\%,20\%, we can calculate the market potential and environmental benefit from the clean transformation of existing district heating network and newly installed district clean heating network.

By calculation shown in Table 4, when clean heating accounts for 5\% of total district heating capacity and $\mathrm{SDH}$ accounts for $5 \%$ of clean heating, SDH installation capacity is 1,200 MW, and the maximum installation area of solar collector is 1.5 million $\mathrm{m}^{2}$. When clean heating accounts for $20 \%$ of total district heating capacity and SDH accounts for $20 \%$ of clean heating, SDH installation capacity would reach to 19,000 MW, and the maximum installation area of solar collector would be 23.8 million $\mathrm{m}^{2}$. 
Table.4 Potential SDH capacity and solar collector area in the clean transformation of existing district heating system SDH loads and Solar collector area in existing district heating system $\left(10^{3} \mathrm{MW}\right)$

\begin{tabular}{|c|c|c|c|c|}
\hline & DH-5\% & DH-10\% & DH-15\% & DH-20\% \\
\hline SDH-5\% & 1.20 & 2.35 & 3.55 & 4.75 \\
\hline SDH-10\% & 2.40 & 4.70 & 7.10 & 9.50 \\
\hline SDH-15\% & 3.60 & 7.05 & 10.65 & 14.25 \\
\hline SDH-20\% & 4.80 & 9.40 & 14.20 & 19.00 \\
\hline \multicolumn{5}{|c|}{ Solar collector area $\left(10^{6} \mathrm{~m}^{2}\right)$} \\
\hline & $\mathrm{DH}-5 \%$ & DH-10\% & DH- $15 \%$ & DH-20\% \\
\hline $\mathrm{SDH}-5 \%$ & 1.50 & 2.94 & 4.44 & 5.94 \\
\hline SDH-10\% & 3.00 & 5.88 & 8.88 & 11.88 \\
\hline SDH- $15 \%$ & 4.50 & 8.81 & 13.31 & 17.81 \\
\hline $\mathrm{SDH}-20 \%$ & 6.00 & 11.75 & 17.75 & 23.75 \\
\hline
\end{tabular}

Note: DH-5\% represents clean heating account for 5\% in clean heating transformation of existing district heating capacity, SDH-5\% represents SDH account for 5\% in clean heating capacity. The rest are similar.

\section{Conclusions}

By above technical and economic analysis, we can summarize a SDH development road map as shown in Table.5.

Table. 5 SDH Development Road Map in China

\begin{tabular}{l|l|l|l}
\hline Steps & Pilot demonstration & Technology accumulation & Technology innovation \\
\hline Years & 2017-2020 & 2021-2025 & 2026-2030 \\
\hline Target market & $\begin{array}{l}\text { Rural area, small } \\
\text { villages, towns }\end{array}$ & $\begin{array}{l}\text { Industrial parks, large } \\
\text { residential communities }\end{array}$ & $\begin{array}{l}\text { Small cities, integration with } \\
\text { existing heating network }\end{array}$ \\
\hline $\begin{array}{l}\text { Technology } \\
\text { application }\end{array}$ & $\begin{array}{l}\text { Solar + GSHP, Solar + } \\
\text { Tank Thermal Storage, } \\
\text { high performance flat } \\
\text { plate solar collector }\end{array}$ & $\begin{array}{l}\text { Low temperature heating, } \\
\text { remote monitoring, } \\
\text { seasonal heat storage }\end{array}$ & $\begin{array}{l}\text { System integration, large } \\
\text { scale solar district heating }\end{array}$ \\
\hline
\end{tabular}

Northern China owns the basic conditions for the implementation of SDH with a developed district heating network. With the national energy saving renovation of existing buildings and clean energy transformation of existing district heating system, development of low temperature heating technology, and more stringent restrictions to coal-fired boilers, heating enterprises must actively look for clean energy alternative to fossil energy, and SDH will be the best choice. There are already some enterprises begin to build pilot and demonstration projects in Tibet, Beijing suburbs and other regions. It is expected there would be many SDH projects finished by the end of 2017.

Even though there are many challenges for SDH in China, we still believe that the implementation of SDH is an inevitable requirement for economic development and environmental protection. The next five years would be the best time to promote SDH with the mature technologies, favorable policies, and huge market potential.

\section{References}

1.http://data.stats.gov.cn/easyquery.htm?cn=C01\&zb=A0B05\&sj=2015

2.Jiang Yi. Study on China's Building Energy Conservation Strategy. "China Engineering Science", 2011, 13 (06): 30-38. "China Construction Annual Development Research 2015")

3.https://www.healtheffects.org/ (GBD MAPS Working Group. Burden of Disease Attributable to CoalBurning and other Major Sources of Pollution in China. 2016. HEALTH EFFECTS INSTITUTE) 
4.http://news.xinhuanet.com/world/2015-09/26/c_1116685873.htm

5.Tsinghua University Building Energy Conservation Research Center. 《China Building Energy Annual Development Research Report 2017》 . China Construction Industry Press. Beijing (2017)

6.http://zfxxgk.nea.gov.cn (National Energy Administration of China)

7. 《Assessment method for solar energy resources》QX/T89-2008

8.Werner Weiss, Monika Spork-Dur, Franz Mauthner. Solar Heat Worldwide 2017(Global Market Development and Trends in 2016 Detailed Market Figures 2015). IEA Solar Heating \& Cooling Programme, (2017)

9.http://www.mohurd.gov.cn/xytj/ (Annual Report of Urban Construction of China(2013)) 10.http://sunstore4.eu/ (DESIGN OF THE OVERALL ENERGY SYSTEM OF THE DEMONSTRATION PLANT AT MARSTAL FJERNVARME)

11.Li Ying.Study on heat balance of ground source heat pump in Severe Cold Area[J]; Journal of Jilin Architectural and Civil Engineering Institute. (2012)

12.http://sunstore4.eu/use-results/sunstore4-tool/

13.Tan Dalu, Zhao Shiqiang. 《GONGCHENGJINGJIXUE》. Wuhan University of Technology. 2012

14. Huang Jianchun. Economic Analysis on the status of urban central heating and research on heating system optimization and energy-saving measures. 《Chang'an University》, 2008

15. Zhou Zhisheng. Economic Analysis of Cogeneration Technology. 《Jilin University》, 2015

16. http://zfxxgk.nea.gov.cn (National Energy Administration of China)

17. X Yang, H Li, S Svendsen. Decentralized substations for low-temperature district heating with no Legionella risk, and low return temperatures. 《Energy》, 2016, 110:65-74

18. Du Lijuan. Research and application of low temperature heating technology. 《BEIJING UNIVERSITY OF CIVIL ENGINEERING AND ARCHITECTURE》, 2016

19. C Flynn, S Kai. Influence of location and design on the performance of a solar district heating system equipped with borehole seasonal storage. 《Renewable Energy》, 2015, 81:377-388

20. $B$ Sibbitt et al. The Performance of a High Solar Fraction Seasonal Storage District Heating System Five Years of Operation. 《Energy Procedia》, 2012, 30(1):856 - 865

22. Zhang Chen, Study On Combined Heating System Of Solar Energy And Gas Wall Hung Boilers In Baoding,2014, University Of Hebei

23. Shen Zhenyu, Xuan Yongmei, Energy Consumption Analysis Of Solar Air Source Heat Pump Heating And Hot Water System, School of environmental and chemical engineering, Xi'an Polytechnic University, 05 issue of 2016, Refrigeration \& Air Conditioning,p544-548

24. Tang Jiayao, Heating System Reform And Regulatory Innovation, Urban Development Research, 2016, 23 (3): 43-48

25. Annual Report On the Annual Development Of Building Energy Conservation In China 2015, Building Energy Conservation Research Center Of Tsinghua University

26. Annual Report On the Annual Development Of Building Energy Conservation In China 2016, Building Energy Conservation Research Center Of Tsinghua University

27. Zhang Wei. Study on heating energy consumption of rural residence in cold area. Tianjin University, 2011

28. Li Yanjun. Study on heating mode of rural residence in Northwest China. Xi'an University Of Architecture And Technology, 2014 